\title{
PENGEMBANGAN MEDIA BIG BOOK ALFABET UNTUK MEMFASILITASI KEMAMPUAN MENGENAL HURUF ALFABET ANAK USIA 4-5 TAHUN
}

\author{
Mega Triana ${ }^{1}$, Sumardi $^{2}$, Taopik Rahman ${ }^{3}$ \\ ${ }^{1}$ Program Studi PGPAUD UPI Kampus Tasikmalaya \\ ${ }^{2}$ Program Studi PGPAUD UPI Kampus Tasikmalaya \\ ${ }^{3}$ Program Studi PGPAUD UPI Kampus Tasikmalaya
}

Email : megatrianafirdaus@gmail.com

(Received: Mei 2020; Accepted: Mei 2020; Published: Juni 2020)

\begin{abstract}
Media is very important in ongoing learning activities, especially in early childhood education, educators are required to use the media when delivering material or when learning takes place. Preliminary study in TK Yayasab Islam in group A that learning media is used every day by teachers. The media that is often used to introduce letters of the alphabet to children is the poster attached to the classroom wall. Media used in kindergartens should be media that can be used or played directly by children, so that children have new experiences and can train the concentration of children. The results of identifying and analyzing the problem, the researchers followed up by designing the alphabet big book media as a solution to improve the ability to recognize the alphabet letters of children aged 4 s.d. 5 years. In this study using the Design Based Research (DBR) method developed by Amiel and Reeves to design, develop, and test the feasibility of a product to overcome problems in learning. The main ingredient of the product is designed using fiber measuring $50 \mathrm{x}$ $37.5 \mathrm{~cm}$, then the fiber is coated by blue, yellow and flannel motifs. A preliminary study of this research was conducted at the Islamic Foundation Kindergarten. Data collection was only done by interviews and expert validation, this was due to the Corona Virus Disease pandemic (COVID-19) so that researchers could not continue product trials in the field. The product design was declared feasible by the three expert validators, then revised according to the suggestions and recommendations of the expert validators. In general, the product is declared suitable for use as a learning medium about the ability to recognize letters of the alphabet of children aged 4 to 5 years.
\end{abstract}

Keywords : learning media, big book alfabet, recognize letters

\begin{abstract}
ABSTRAK
Media sangat penting dalam berlangsungnya kegiatan pembelajaran, apalagi dalam pendidikan anak usia dini, pendidik dituntut untuk menggunakan media pada saat menyampaikan materi atau pada saat pembelajaran berlangsung. Studi pendahuluan di TK Yayasan Islam pada kelompok A bahwa media pembelajaran digunakan setiap hari oleh guru. Media yang sering digunakan untuk mengenalkan huruf alfabet kepada anak yakni poster yang menempel didinding kelas. Media yang digunakan di taman kanakkanak sebaiknya media yang bisa digunakan atau dimainakan langsung oleh anak, agar anak memiliki pengalaman baru serta dapat melatih konsentrasi anak. Hasil identifikasi dan menganalisis masalah tersebut, peneliti menindak lanjuti dengan merancang media big book alfabet sebagai solusi untuk meningkatkan kemampuan mengenal huruf alfabet anak usia 4 s.d. 5 tahun. Dalam penelitian ini menggunakan metode Design Based Research (DBR) yang dikembangkan oleh Amiel dan Reeves untuk merancang, mengembangkan, dan menguji kelayakan suatu produk untuk mengatasi permasalahan dalam pembelajaran. Bahan utama produk dirancang menggunakan fiber berukuran $50 \times 37,5 \mathrm{~cm}$, kemudian fiber tersebut dilapisi oleh kain flanel berwarna biru, kuning, dan motif polkadot. Studi pendahuluan penelitian ini dilakukan di TK Yayasan Islam. Pengumpulan data hanya dengan wawancara dan validasi ahli saja, hal ini dikarenakan adanya pandemik Corona Virus Disease (COVID-19) sehingga peneliti tidak bisa melanjutkan uji coba produk ke lapangan. Rancangan produk dinyatakan layak oleh ketiga validator ahli, kemudia melakukan revisi sesuai saran dan rekomendasi dari validator ahli. Secara umum produk dinyatakan layak digunakan sebagai media pembelajaran tentang kemampuan mengenal huruf alfabet anak usia 4 s.d. 5 tahun.
\end{abstract}

Keywords: Media pembelajaran, big book alfabet, mengenal huruf. 
PENDAHULUAN

Anak didik adalah manusia yang harus di pandang sebagai subjek, setiap anak memiliki pribadi yang berbeda sehingga harus diberi kebebasan dalam mewujudkan dirinya sendiri untuk mencapai kedewasaan (Syaripudin dan Kurniasih, 2017, hlm. 65)

$$
\text { Taman Kanak-kanak }
$$

merupakan lembaga formal yang memberikan layanan pendidikan kepada anak usia dini pada rentang usia 4-6 tahun yang bertujuan untuk membantu mengembangkan berbagai potensi yang ada dalam diri anak baik fisik maupun psikis yang meliputi agama, moral, sosial, emosional, kemandirian, kognitif, bahasa, fisik motorik dan seni untuk persiapan ke tahap pendidikan yang lebih lanjut (Gusnita, dkk: 2019)

Ada enam aspek perkembanngan yang harus dioptimalkan oleh anak usia dini, salah satu nya adalah aspek bahasa. Aspek bahasa perlu dipersiapkan dan dikembangkan untuk menghadapi jenjang pendidikan selanjutnya yaitu kemampuan mengenal huruf. Kemampuan mengenal huruf merupakan kemampuan yang terlihat sederhana. Menurut Rislina dan Khan (2015) untuk bisa membaca anak harus terlebih dahulu menghafalkan semua bentuk huruf kecil maupun besar. Sebelum mengenal kalimat agar dapat lancar membaca langkah awal yang diharuskan adalah memahami dan menghafalkan huruf-huruf yang ada. Jika pemahaman tentang huruf kurang maka kemampuan menguasai kalimat atau membaca kurang.

Bahasa adalah alat komunikasi yang dapat membangun interaksi antara individu dengan individu lainnya. Dengan bahasa seseorang dapat mengemukakan pendapat, ide dan gagasannya. Bahasa dapat membuat anak-anak lebih imajinatif, mengubah (manipulasi), menciptakan gagasan-gagasan baru dan membagi gagasan-gagasan itu dengan anak lain (Yuliana Nurani Sujiono, dkk., 2014: 4-10 dalam Pangastuti dan Hanum, 2017).

Perkembangan bahasa dimulai dari lingkungan yang sederhana melalui praktek secara langsung. Menurut Wiyani (2014) perkembangan bahasa pada anak usia dini adalah perubahan sistem lambang bunyi yang berpengaruh terhadap kemampuan berbicara anak usai dini. Dengan kemampuan berbicaranya itu anak usia dini bisa mengidentifikasi dirnya, serta berinterksi dan bekerja sama dengan orang lain.

Ada enam aspek perkembanngan yang harus dioptimalkan oleh anak usia dini, salah satu nya adalah aspek bahasa. Aspek bahasa perlu dipersiapkan dan dikembangkan untuk menghadapi jenjang pendidikan selanjutnya yaitu kemampuan mengenal huruf. Kemampuan mengenal huruf merupakan kemampuan yang terlihat sederhana.

Aspek perkembangan bahasa terbagi menjadi beberapa aspek, salah satunya adalah keaksaraan. Tertulis pada Standar Tingkat Pencapaian Perkembanagan Anak 
bahwa anak usia 4-5 tahun dapat mengenal simbol-simbol, mengenal suara-suara hewan/ benda yang ada disekitarnya, membuat coretan yang bermakna dan meniru huruf alfabet.

Namun dengan demikian, dalam pelaksanaan pembelajaran tidak semua aspek-aspek perkembangan dapat berkembang secara optimal. Ada saja hambatan-hambatan yang terjadi pada saat pembelajaran, misalnya ketika meniru huruf alfabet dengan cara menulis anak akan merasa bosan dan jenuh saat melakukan pembelajaran menulis. Padahal untuk mengembangkan keterampilan membaca anak harus mengetahui semua huruf alfabet. Terkadang pendidik mengalami kesulitan dalam memberikan pembelajaran mengenal huruf. Jumlah huruf yang lumayan banyak sulit dihafalkan oleh anak-anak.

Melihat hasil dari lapangan, bahwa di TK Yayasan Islam pada anak kelompok A masih banyak belum mengenal huruf-huruf alfabet. Misalnya anak sering kali tertukar menyebutkan huruf satu dengan huruf yang lainnya. Dalam aspek bahasa khususnya kemampuan mengenal huruf, anak kelompok A TK Yayasan Islam masih rendah. Rendahnya pengenalan huruf alfabet kepada anak usia dini akan berdampak buruk bagi anak, dampak ini akan terasa pada saat anak melanjutkan pendidikan ke jenjang selanjutnya (Sekolah Dasar). Permasalahan pembelajaran mengenal huruf di TK Yayasan Islam yaitu kurangnya alat atau media yang menarik perhatian anak pada saat mengenalkan huruf-huruf alfabet. Jadi guru hanya menunjkan huruf-huruf alfabet yang ada di dinding kelas saja sehingga anak kurang fokus terhadap apa yang di sampikan oleh guru.

Maka dari itu, dalam penelitian ini penulis berupaya untuk mengembangkan media big book alfabet,media ini diharapkan dapat digunkan guru untuk memfasilitasi kemampuan mengenal huruf alfabet pada anak sesuai dengan kompetensi dasar yang diinginkan.

\section{TINJAUAN PUSTAKA}

A. Pengertian Kemampuan Mengenal Huruf

Menurut Rislina dan Kan (2015 : 158) "Mengenal huruf merupakan kegiatan kognitif yang distimulus melalui pendengaran dan penglihatan. Kemampuan mengenal huruf dimulai sejak dini, anak senang mengekspolorasi buku dengan cara memegang atau membolak balik buku".

Kemampuan mengenal huruf di Taman kanak-kanak dilakasanakan dalam batas-batas aturan, pembelajaran mengenal huruf di TK hendaknya diberikan secara terpadu khususnya dalam aspek perkembangan bahasa "Salah satu cara untuk meningkatkan kemampuan mengenal huruf anak adalah dengan mengadakan variasi belajar dalam kegiatan pembelajaran yang dilakukan”. (Nawafilaty, 2017 : 
Jadi mengenalkan huruf kepada anak harus sesuai dengan perkembangan yang dimiliki oleh setiap anak. Guru atau orang tua harus dapat menuntun dan menstimulus kemampuan yang dimiliki setiap anak. Menyampaikan materi pengenalan huruf pada anak harus memiliki sifat kebermaknaan agar anak tidak merasa bosan dan terpaksa, misalnya : menggunakan media pengenalan huruf agar anak menarik dan semangat ketika melakukan pembelajaran.

Selain itu, kemampuan mengenal huruf memiliki manfaat bagi setiap anak, salah satunya yaitu anak memiliki kosa kata yang lebih banyak dan meningkatkan keterampilan membaca. Ketika kedua manfaat tersebut dimiliki oleh anak, maka anak akan siap ketika masuk ke jenjang pendidikan selanjutnya dan anak mampu berinteraksi dengan orang lain.

\section{Media}

\section{A. Pengertian Media}

Menurut Azhar Arsyad (2013, hlm 3) "kata media berasal dari bahasa Latin yaitu medius yang secra harfiah berarti 'tengah', 'perantara', atau 'pengantar'. Dalam bahasa Arab, media adalah perantara atau pengantar pesan dari pengirim kepada penerima".

"Media pembelajaran adalah alat atau sarana untuk membantu proses belajar megajar dan berfungsi untuk penyampaian pesan agar terlihat jelas, sehingga dapat mecapai tujuan pembelajaran menjadi lebih optimal" (Sutjipto dan Kustandi,2011, hlm 9).

Jadi media sangat penting dalam berlangsungnya kegiatan pembelajaran, apalagi dalam pendidikan anak usia dini, pendidik dituntut untuk menggunakan media pada saat menyampaikan materi atau pada saat pembelajaran berlangsung. Tetapi ketika menggunakan media pada saat pembelajaran, guru harus cermat dalam memilihnya, misalnya : melihat kegunaan atau manfaat media yang akan digunakan, melihat keamanan media (tidak boleh berbahan tajam) agar terhindar dari kejadian yang tidak diinginkan dan agar anak terasa nyaman ketika menggunakan media tersebut.

\section{B. Jenis-jenis Media Pembelajaran}

Menerut Zaman dan Eliyawati (2010) ada tiga jenis media pembelajaran, yaitu :

1) Media Visual

Media visual adalah media yang dapat dilihat. Media visual ini seringkali digunakan oleh guru untuk membantu penyampaian tema yang akan di pelajari. Media visual terbagi menjadi dua jenis, yaitu media yang dapat diproyeksikan (projected visual) dan media yang tidak dapat diproyeksikan (non- projected visual).

Media visual yang diproyeksikan adalah media yang menggunakan alat proyeksi atau menggunakan proyektor, 
materi yang akan disampaikan oleh guru nampak pada layar (screen). Media proyeksi ini bisa berbentuk gambar diam atau gambar bergerak (video). Media visual yang tidak dapat diproyeksikan adalah media gambar diam/ mati, media grafis, media model, media realia.

2) Media Audio

Media audio adalah medi yang berbantu auditif (hanya dapat didengar) yang merangsang pikiran, perasaan, perhatian dan kemauan anak untuk mempelajari tema. Contoh media audio adalah $\mathrm{CD}$, radio, dsb. Penggunaan audio dalam kegiatan pembelajaran anak usia dini bertujuan untuk melatih aspek keterampilan mendengarkan.

3) Media Audio Visual

Media audio visual adalah media kombinasi dari media audio dan media visual atau biasa disebut media pandangdengar. Media audio visual merupakan media yang lengkap dalam menyampaikan pembelajaran pada anak, karena penyajian isi tema akan semakin lengkap dan optimal. Guru tidak sangat berperan ketika saat menyampaikan media ini, dalam media ini guru cukup menjadi fasilitator atau memberi kemudahan pada anak ketika pembelajaran.

\section{Pengertian Media Big Book Alfabet}

$$
\text { "Buku Besar (Big Book) }
$$

adalah buku bacaan yang memiliki ukuran, tulisan, dan gambar yang besar. Big Book berkarakteristik khusus yang dibesarkan, baik teks maupun gambarnya, sehingga memungkinkan terjadinya kegiatan membaca bersama antara guru dan murid. Ukuran Big Book bisa beragam, misalnya ukuran A3, A4, A5, atau seukuran koran. Ukuran Big Book harus mempertimbangkan segi keterbacaan seluruh siswa di kelas". (Mu'awwanah, 2018, hlm. 324)

"Big book merupakan buku cerita yang berkarakteristik khusus yang dibesarkan, baik teks maupun gambarnya, sehingga memungkinkan terjadinya kegiatan membaca bersama antara guru dan murid. Buku ini mempunyai karakteristik khusus seperti penuh warna-warni, memiliki kata yang dapat diulang-ulang, mempunyai alur cerita yang mudah ditebak, dan memiliki pola teks yang sederhana" (Karges dalam Solehuddin, dkk. 2008:7).

Selain itu menurut Mu'awwanah (2018:324) "Big Book dapat digunakan di kelas awal karena memiliki karakteristik yang sesuai dengan kebutuhan siswa. Guru dapat memilih Big Book yang isi cerita dan topiknya sesuai dengan minat siswa atau sesuai dengan tema pelajaran. Bahkan, guru dapat membuat sendiri Big Book sesuai dengan karakteristik dan kebutuhan siswa".

Curtain dan Dahlberg (dalam Sulaiman, 2017 : 196) menyatakan 
bahwa "big book memungkinkan siswa belajar membaca melalui cara mengingat dan mengulang bacaan. Banyak ahli pendidikan yang menyatakan bahwa big book sangat baik dipergunakan di kelas awal karena dapat membantu meningkatkan minat siswa dalam membaca".

Jadi big book adalah media pembelajaran yang berukuran besar sehingga ukurannya harus terlihat oleh seluruh siswa di dalam kelas. Selain itu big book bisa digunakan di kelas awal karena memiliki karakteristik yang disesuaikan dengan kebutuhan siswa. Melihat karakteristik tersebut, big book dapat digunakakan untuk pendidikan anak usia dini.

METODE

Metode penelitian yang digunakan dalam penelitian ini adalah Design Based Research (DBR). Penelitian ini dilaksanakan untuk mengembangkan prototype dalam pembelajaran mengenal huruf alfabet anak usia 4 s.d. 5 tahun.

\section{A. Rancangan Penelitian}

Tujuan metode Design Based Research (DBR), yaitu untuk memecahkan permasalahan dalam bidang pendidikan melalui pembuatan produk dengan mengintegrasikan desain dan serta untuk menguji kelayakan produk yang dihasilkan, yaitu media big book alfabet. Adapun prosedur metode DBR adalah sebagai berikut (Amiel dan
Reeves, 2008):

1. Analysis of practical problems by researches and practitioners in collaboration (identifikasi dan analisis masalah oleh peneliti dan praktisi secara kolaboratif).

2. Development of solutions informed by existing design principles and technological innovations (mengenmbangkan prototype solusi yang didasarkan pada patokan teori, design principle yang ada dan inovasi teknoligi)

3. Iterative cycles of testing and refinement of solutions in practice (melakukan proses berulang untuk menguji dan memperbaiki solusi secara praktis)

4. Reflection to produce "design principles" and enhance solution implementation (refleksi untuk menghasilkan design principle serta meningkatkan implementasi dari solusi secara praktis).

Berdasarkan penjelasan diatas, sebelum peneliti sebelum peneliti mengembangkan produk, terlebih dahulu peneliti melakukan studi pendahuluan sebagai langkah utama untuk mendapatkan informasi terkait permasalahan yang ditemukan. Dari hasil temuan yang diperoleh peneliti membuat rancangan desain produk media big book alfabet untuk memfasilitasi kemampuan mengenal huruf anak usia 4 s.d 5 tahun yang selanjutnya akan di validasi oleh 
ahli, sampai akhirnya produk itu layak digunakan.

\section{B. Teknik Pengumpulan Data}

Teknik pengumpulan data adalah guna memperoleh data yang dibutuhkan, pada penelitian ini ada beberapa teknik pengumpulan data yang dibutuhkan, yaitu :

1) Wawancara

Menurut Hermawan, dkk. (2010, hlm. 178) "wawancara adalah pengumpulan data dengan mengajukan pertanyaan secara langsung oleh pewawancara kepada responden dan jawaban responden dicatat atau direkam”. Peneliti menggunakan teknik wawancara terstruktur. Teknik wawancara terstruktur merupakan wawancara dengan guru dalam pembelajaran. Wawancara dilaksanakan kepada guru kelompok A TK Yayasan Islam.

Nama : Siti Aisyah, S.Pd.

Alamat : Jl. H. Ma'mun Sodik No. 50, Panglayungan, Kec. Cipedes

Pekerjaan : Guru Kelompok A

Hari dan tanggal : 20 November 2019

Tabel 1

\begin{tabular}{|l|l|l|}
\hline No & Pertanyaan & \multicolumn{1}{|c|}{ Jawaban } \\
\hline & Apakah Ibu & Setiap hari atau \\
& selalu & setiap lingkup \\
& menggunakan & perkembangan \\
& media & menggunakan \\
& pembelajaran & media \\
& untuk & pembelajaran. \\
\hline
\end{tabular}

\begin{tabular}{|c|c|}
\hline $\begin{array}{l}\text { menyampaikan } \\
\text { materi? }\end{array}$ & \\
\hline $\begin{array}{l}\text { Media } \\
\text { pembelajaran } \\
\text { seperti apa yang } \\
\text { sering Ibu } \\
\text { gunakan untuk } \\
\text { menyampaikan } \\
\text { materi? }\end{array}$ & $\begin{array}{l}\text { Media berupa } \\
\text { gambar, benda } \\
\text { asli atau video } \\
\text { tergantung } \\
\text { materi yang } \\
\text { disampaikan. }\end{array}$ \\
\hline $\begin{array}{l}\text { Menurut Ibu, } \\
\text { bagaimana } \\
\text { media } \\
\text { pembelajaran } \\
\text { yang ideal } \\
\text { digunakan } \\
\text { dalam KBM? }\end{array}$ & $\begin{array}{l}\text { Media yang } \\
\text { jelas, misal } \\
\text { ketika } \\
\text { menerangkan } \\
\text { buah apel } \\
\text { sebaiknya } \\
\text { gunakan buah } \\
\text { apel yang asli. } \\
\text { Jadi anak dapat } \\
\text { melihat bentuk, } \\
\text { warna, ukuran } \\
\text { yang jelas. }\end{array}$ \\
\hline $\begin{array}{l}\text { Media } \\
\text { pembelajaran } \\
\text { apa yang dapat } \\
\text { memfasilitasi } \\
\text { kemampuan } \\
\text { mengenal huruf } \\
\text { dalam KBM? }\end{array}$ & $\begin{array}{l}\text { Poster yang di } \\
\text { tempel di } \\
\text { dinding, } \\
\text { tayangan- } \\
\text { tayangan dari } \\
\text { youtube, puzzle } \\
\text { huruf dan } \\
\text { stempel huruf. }\end{array}$ \\
\hline $\begin{array}{l}\text { Apakah media } \\
\text { pembelajaran } \\
\text { untuk } \\
\text { memfasilitasi } \\
\text { kemampuan } \\
\text { mengenal huruf }\end{array}$ & $\begin{array}{l}\text { Disediakan dan } \\
\text { membuat } \\
\text { sendiri. }\end{array}$ \\
\hline
\end{tabular}




\begin{tabular}{|c|c|}
\hline $\begin{array}{l}\text { sudah } \\
\text { disediakan oleh } \\
\text { sekolah atau } \\
\text { Ibu } \\
\text { membuatnya } \\
\text { sendiri? }\end{array}$ & \\
\hline $\begin{array}{l}\text { Menurut Ibu, } \\
\text { bagaimana } \\
\text { media } \\
\text { pembelajaran } \\
\text { yang cocok } \\
\text { untuk } \\
\text { memfasilitasi } \\
\text { kemampuan } \\
\text { mengenal huruf } \\
\text { anak? }\end{array}$ & $\begin{array}{l}\text { Media yang } \\
\text { menarik } \\
\text { perhatian anak } \\
\text { sehingga ketika } \\
\text { anak sedang } \\
\text { menggunakan } \\
\text { media tersebut } \\
\text { terasa seperti } \\
\text { bermain. }\end{array}$ \\
\hline $\begin{array}{l}\text { Apa kendala } \\
\text { Ibu saat } \\
\text { menggunakan } \\
\text { media yang } \\
\text { memfasilitasi } \\
\text { kemampuan } \\
\text { mengenal huruf } \\
\text { anak? }\end{array}$ & $\begin{array}{l}\text { Dikarenakan } \\
\text { setiap anak } \\
\text { berbeda } \\
\text { karakrter dan } \\
\text { pekembangan- } \\
\text { nya jadi kendala } \\
\text { saya ketika } \\
\text { sudah diberi } \\
\text { media yang } \\
\text { jelas tetapi } \\
\text { masih ada yang } \\
\text { belum } \\
\text { memahami. } \\
\text { Dan masih ada } \\
\text { anak yang sama } \\
\text { sekali belum } \\
\text { hafal huruf } \\
\text { alfabet, ada } \\
\text { anak yang }\end{array}$ \\
\hline
\end{tabular}

\begin{tabular}{|l|l|l|}
\hline & $\begin{array}{l}\text { masih tertukar } \\
\text { ketika } \\
\text { menunjukan } \\
\text { dan } \\
\text { menyebutkan } \\
\text { huruf. }\end{array}$ \\
\hline $\begin{array}{l}\text { Apakah } \\
\text { harapan Ibu } \\
\text { berkenaan } \\
\text { dengan } \\
\text { pengembangan } \\
\text { media } \\
\text { pembelajaran } \\
\text { big book } \\
\text { alfabet } ?\end{array}$ & $\begin{array}{l}\text { Agar anak tau } \\
\text { mengenai } \\
\text { pengenalan } \\
\text { huruf, } \\
\text { menambah kosa } \\
\text { kata anak, agar } \\
\text { anak mau } \\
\text { mengikuti } \\
\text { kegiatan } \\
\text { pembelajaran. }\end{array}$ \\
\hline
\end{tabular}

2) Judgement

Penilaian para ahli ini penting dilaksanakan untuk memvalidasi produk. Para ahli akan meninjau produk yang dirancang dan melihat kesesuaian produk dengan permasalahan yang diambil dan kelayakan produk. Para ahli yang akan meninjau produk adalah ahli bahasa, ahli pedagogik dan ahli media pembelajaran.

\section{Analisis Data}

Menurut Miles dan Huberman (Sugiyono, 2015: 369) analisis data dalam penelitian kualitatif dilakukan pada saat pengumpulan data berlangsung dan setelah selesai pengumpulan data dalam periode tertentu. Analisis dilakukan dalam bentuk interaktif dengan 
proses yang berlanjut, berulang, dan terus menerus hingga membentuk suatu siklus dan menghasilkan data yang jenuh. Ada 3 komponen analisis yaitu reduksi data, sajian data, dan penarikan kesimpulan atau verifikasi.

\section{HASIL DAN PEMBAHASAN}

Penelitian ini menggunakan pendekatan kualitatif dengan metode Design Based Research (DBR), yang bertujuan untuk membahas temuan data dilapangan berupa permasalahan yang dihadirkan dengan solusi berdasarkan rumusan masalah yang telah dibuat. Dari hal tersebut, peneliti akan membahas tentang hasil identifikasi dan analisis masalah berkaitan dengan kebutuhan dasar penggunaan media pembelajaran untuk memfasilitasi kemampuan mengenal huruf alfabet, menjelaskan rancangan media big book alfabet. Dikarenkan sistuasi dan kondisi saat ini adanya pandemik covid-19, peneliti tidak menlajutkan uji coba lapangan karena situasi pendidikan saat ini dilakukan dengan cara daring jadi siswa belajar dirumah masing-masing. Pada poin ini hanya ada dua pembahasan yang akan di paparkan, yakni :

\section{Identifikasi dan Analisis Masalah}

Tahap pertama dari peneilitian ini adalah menganalisis masalah. Peneiliti melakukan studi literatur berdasarkan kebutuhan teori atau kajian pustaka. Tahap pertama penelitian ini, peneliti melakukan studi lapangan ke TK
Yayasan Islam. Peneliti melakukuan wawancara dengan guru kelas kelompok A TK Yayasan Islam yang bertempat di Jalan H. Ma'mun Sodiq No.01, Kecamatan Cipedes, Kota Tasikmalaya.

\section{a. Deskripsi Temuan Kebutuhan} Lapangan

Dalam studi pendahuluan ke lapangan, peneiliti melakukan wawancara kepada guru kelas A TK Yayasan Islam. Wawancara ini dilakukan untuk mencari tahu atau mendapatkan informasi kebutuhan lapangan yakni kemampuan mengenal huruf alfabet pada anak kelompok A dan hambatan anak dalam mengenal huruf alfabet. Berikut hasil wawancara dengan guru Kelompok A TK Yayasan Islam :

Nama Narasumber : Siti Aisyah S.Pd. Guru : Kelompok A

Hasil wawancara :

Berdasarkan hasil wawancara dengan guru Kelompok A, peneliti memperoleh informasi bahwa kemampuan mengenal huruf alfabet Kelompok A TK Yayasan Islam masih kurang dikarenakan ada beberapa faktor masalah yang berbeda misalnya ada yang sama sekali dirumahnya tidak dikenalkan huruf-huruf alfabet oleh orangtuanya sehingga jika di sekolah anak tersebut tertinggal jika belajar pengenalan huruf alfabet, ada yang pendiam jadi sama sekali tidak berbicara ketika dikenalkan huruf-huruf alfabet, dan rata-rata permasalahan yang terjadi di Kelompok 
A TK Yayasan Islam ini ketika belajar pengenalan huruf alfabet anak hanya bisa menyebutkan huruf-huruf saja tanpa tahu simbol-simbol huruf-nya.

Selain itu, pengalaman saya ketika mengajar di sekolah tersebut pada saat pengenalan huruf alfabet kepada anak, media yang digunakannya kurang menarik jadi pada saat pembelajaran pengenalan huruf anak kurang fokus kepada guru yang sedang menjelaskan. Media yang digunakan-nya hanya berbentuk poster yang menempel di dinding kelas saja sehingga anak mudah bosan dan kurang fokus ketika guru sedang menjelaskan. Ketika saya membahas kepada narasumber mengenai media pembelajaran pengenalan huruf alfabet memang beliau mengakui mungkin memang media yang kami gunakan kurang menarik bagi anak sehingga anak kurang fokus dala mengikuti pembelajaran-nya. Beliau juga mengatakan bahwa belum sempatnya mengupgrade media-media yang ada di sekolah tersebut dikarenakan satu dari lain hal ada tugas yang harus segera di selesaikan jadi narasumber memanfaatkan media yang ada.

Saat ini sudah semakin berkembang permainan atau alat main yang diperuntukkan bagi anak usia dini, namun jika dilihat dari segi keamanan dan kebermanfaatan terhadap perkembangan anak, banyak ditemukan permainan yang tidak berdampak dalam mengoptimalkan perkembangan anak, hanya segi kesenangan anak saja yang didapatkan. Guru kelompok A TK Yayasan Islam berharap dapat memfasilitasi kreativitas anak melalui permainan yang tepat dan menyenangkan sehingga anak tertarik untuk ikut terlibat dalam kegiatan.

\section{b. Deskripsi Hasil Studi Literatur}

Studi litertaur ini dilakukan untuk mengetahui informasi kemampuan mengenal huruf anak usia dini khususnya usia 4-5 tahun atau anak Kelompok A. Peneliti menemukan menurut Rislina dan Kan (2015 : 158) "Mengenal huruf merupakan kegiatan yang melibatkan unsur kognitif yang dirangsang melalui pendengaran dan penglihatan. Kemampuan mengenal huruf dimulai ketika anak senang mengeksplorasi buku dengan cara memegang atau membolakbalik buku yaitu pada dunia pendidikan anak atau sering disebut TK". Selain itu, "Salah satu cara untuk meningkatkan kemampuan mengenal huruf anak adalah dengan mengadakan variasi belajar dalam kegiatan pembelajaran yang dilakukan". (Nawafilaty, 2017 : 22).

Studi literatur dilakukan pada buku-buku, jurnal, peraturan pemerintah yang berkaitan dengan media pembelajaran untuk memfasilitasi perkembangan anak usia dini. Dari studi literatur yang dilakukan, peneliti menemukan untuk mengatasi 
permasalahan tersebut dilapangan, peneliti memilih media pembelajaran yakni media big book alfabet yang dapat memfasilitasi kemampuan mengenal huruf anak usia dini.

2. Rancangan Media Big Book Alfabet untuk Memfasilitasi Kemampun Mengenal Huruf Alfabet Anak Usia 4 s.d. 5 Tahun.

Peneliti mengidentifikasi dan menganalisis permasalahan yang ada di TK Yayasan Islam khususnya pada kelompok A dengan merancang sebuah media pembelajaran berupa big book alfabet, untuk dijasikan solusi permasalahan di sekolah tersebut, permasalahan mengenai kemampuan mengenal huruf anak usia 4 s.d. 5 tahu atau kelompok $\mathrm{A}$.

Berikut adalah rancangan peneliti dalam pengembangan media big book alfabet untuk memfasilitasi kemampuan mengenal huruf anak usia 4 s.d. 5 tahun.

Tabel 2

Alat dan bahan media big book alfabet

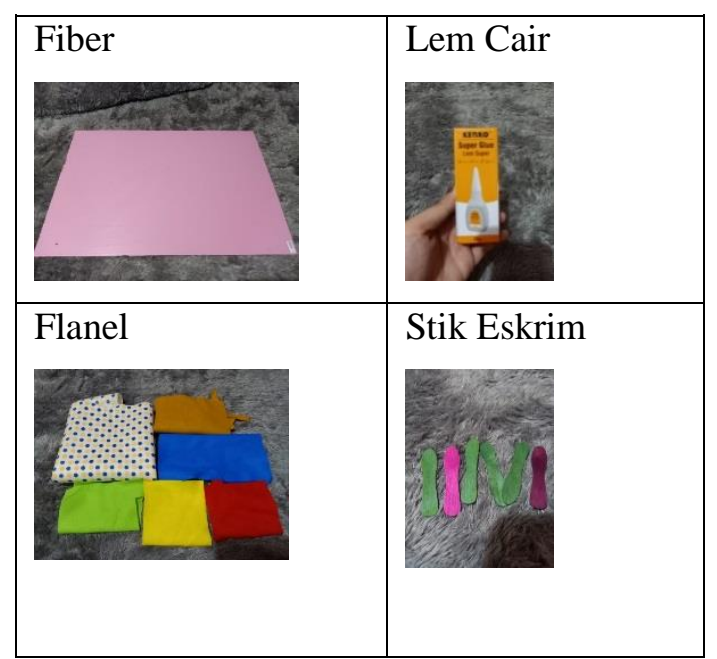

\begin{tabular}{|l|l|}
\hline Pulpen & Benang \\
\hline Gunting & Larum \\
\hline Cutter & Lertas dan Printer \\
\hline Alat lem tembak & \\
\hline
\end{tabular}


3. Proses Pembuatan Media Big Book Alfabet untuk Memfasilitasi Kemampuan Mengenal Huruf Alfabet Anak Usia 4 s.d. 5 Tahun

Pada proses pembuatan produk media big book alfabet diawali dengan menganalisis kirukilum 2013 PAUD. Analisis kurikulum meliputi Kompetensi Inti, Kompetensi Dasar, Indikator pencapaian perkembangan, tujuan pembelajaran, materi dan media pembelajaran untuk memfasilitasi kemampuan mengenal huruf alfabet.

Selanjutnya peneliti membuat dasar membuaut dasar pengembangan produk yang yang merupakan ide dasar atau gambaran umum dari media yang akan digunakan, serta membuat strory board yang berisi desain dari media yang dibuat oleh peneliti.

\section{Tabel 3}

Storyboard media big book alfabet

\begin{tabular}{|c|c|c|}
\hline No & Tampilan & Keterangan \\
\hline 1. & $\begin{array}{c}\frac{\text { Big }}{\text { Book }} \\
\text { Alfabet }\end{array}$ & $\begin{array}{l}\text { Tampilan } \\
\text { Depan } \\
\text { (cover) } \\
\text { Judul Media }\end{array}$ \\
\hline 2. & & $\begin{array}{l}\text { Halaman } 1 \\
\text { Media: } \\
\text { Pengenalan } \\
\text { media big } \\
\text { book alfabet } \\
\text { secara singkat }\end{array}$ \\
\hline
\end{tabular}

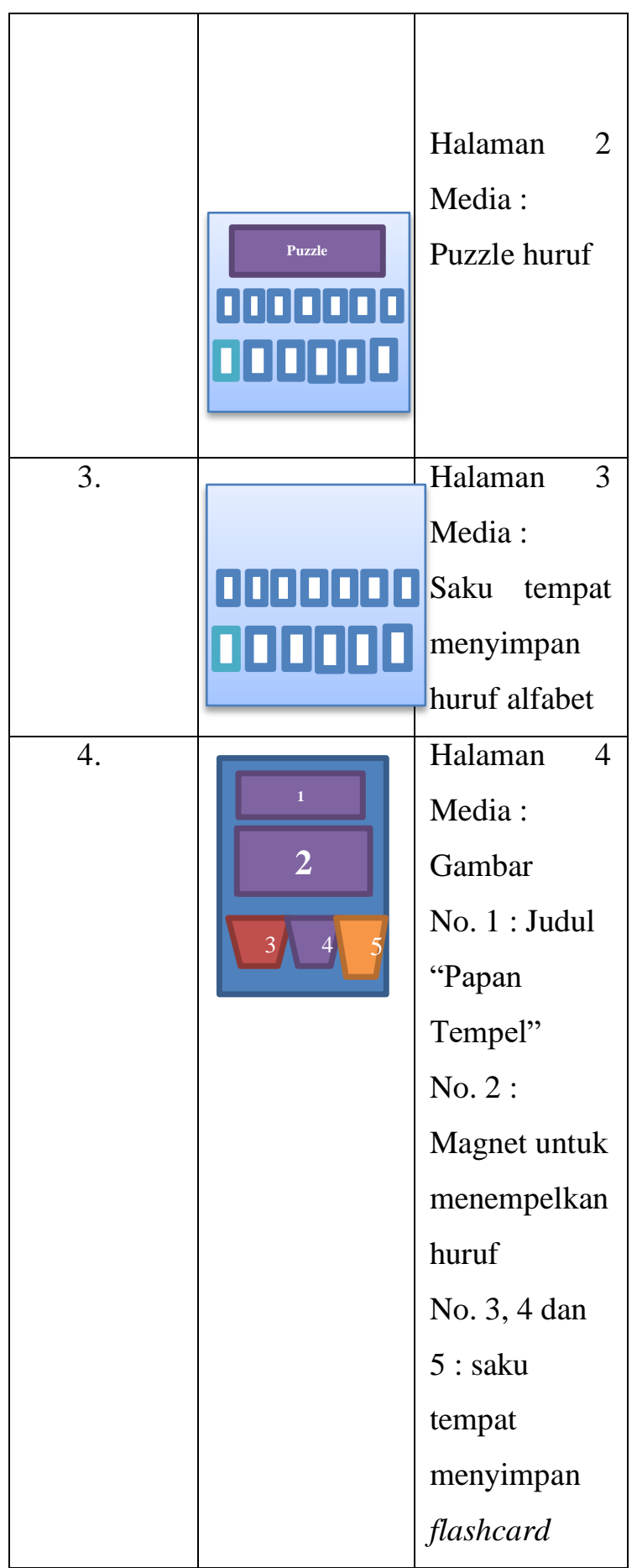

Media big book alfabet adalah media yang memiliki bentuk seperti buku besar, di dalamnya yang berisikan hurufhuruf alfabet, papan untuk menyusun huruf dan di dalamnya terdapat media kartu huruf bergambar (flashcard). Flashcard yang digunakan pada media 
big book ini berukuran $7,5 \mathrm{~cm} \times 7,5 \mathrm{~cm}$. Big Book alfabet termasuk pada jenis media visual yang tidak diproyeksikan (non- projected visual). Big book alfabet berbahan dasar fiber berukuran 50 x 37,5 $\mathrm{cm}$, fiber tersebut dilapisi oleh kain flanel agar tidak berbahaya bagi anak. Peneliti membuat potongan fiber yang dilapisi kain flanel sebanyak empat buah, kemudian ujung fiber yang sudah dilapisi diberi perekat yang akhirnya berbentuk seperti lembaran-lembaran buku. Objek yang digunakan dalam penelitian ini adalah puzzle huruf, flashcard berukuran 7,5 x 7,5 cm, dan huruf-huruf alfabet yang terbuat dari kayu. Objekobjek yang digunakan ditempelkan di bagian dalam big book atau di beberapa halam big book alfabet.

Setelah produk dirancang dan dibuat, selanjutnya ke tahap validasi produk yang dilakukan oleh beberap validator ahli. Pada tahap validasi dilakukan oleh tiga validator ahli, yaitu ahli konten keilmuan (bidang bahasa) yang mengkaji dan menganalisis tentang konten media pembelajaran big book alfabet dalam pembelajaran mengenal huruf alfabet,, ahli dalam media pembelajaran mengkaji dan menganalisis tentang keseluruhan media pembelajaran yang telah dirancang, dibuat, dari segi tampilan, bahan, dan kesesuaian media dengan kontteks pembelajaran mengenal huruf alfabet, dan ahli dalam bidang pedagogik yaitu mengkaji dan menganalisis dari segi kebermanfaatan serta kesesuaian dengan media pembelajaran untuk anak usia 4 s.d 5 tahun atau anak kelompok A.

Ketiga validator ahli menyatakan bahwa media big book alfabet sudah layak untuk di uji cobakan ke sekolah, setelah memperbaiki sesuai saran dan rekomendasi yang telah diberikan. Hasil dari perbaiikan dan revisi produk seharusnya penliti melakukan tahap selanjutnya yaitu melakukan uji coba produk ke lapangan. Tetapi telah peneliti jelaskan diatas, bahwa penelitian ini hanya sampai ke validasi produk saja, karena dengan adanya pandemik penyebaran wabah virus covid-19, situasi dan kondisi seperti ini peneliti tidak memungkinkan untuk melakukan uji coba produk ke lapangan.

\section{KESIMPULAN}

Berdasarkan hasil penelitian tentang pengembangan media big book alfabet untuk memfasilitasi kemampuan mengenal huruf alfabet anak usia 4 s.d. 5 tahun dapat disumpulkan sebagai berikut :

1. Media pembelajaran pada sekolah yang diteliti hampir setipa hari menggunakan media pembelajaran. Media pembelajaran untuk memfasilitasi kemampuan mengenal huruf memang sudah mempunyai media-nya tetpai hasa media yang sederhana seperti poster alfabet yang ditempelkan pada tembok kelas. Belum tersedianya media big 
book alfabet khususnya untuk memfasilitasi kemampuan mengenal huruf.

2. Pengembangan media big book alfabet untuk memfasilitasi kemampuan mengenal huruf alfabet ini dibuat berdasarkan permasalahan dilapangan yang peneliti temukan saat melakukan studi pendahuluan, permasalahan yang peneliti temukana berada pada kelompok A. Didukung dengan studi literatur yang merupakan bagian dari pemecahan masalah agar mendapatkan solusi yang diharapkan. Kemudian peneliti melakukan pengembangan produk dengan menganalisis kurikulum, kemudian menyusun storyboard yang dibuat dengan bahan utama yaitu fiber, kain flanel, lem tembak, benang, kayu, huruf alfabet. Setelah media sudah jadi maka tahap selanjutnya adalah validasi terhadap produk yang telah dibuat oleh peneliti dengan melibatkan validator ahli sesuai dengan bidangnya masingmasing. Ada tiga validator yang peneliti pilih yaitu validator ahli konten keilmuan, validator ahli media pembelajaran dan validator ahli pedagoogik.

3. Setelah di validasi seharusnya peneliti melakukan implementasi / uji coba produk ke lapangan. Tetapi dengan adanya pandemik covid-19 peneliti tidak bisa melanjutkan ke tahap berikutnya dikarenakan situasi pendidikan pada saat pandemik seperti ini dilakukan dirumah masing-masing dengan cara daring. Jadi penelitian ini hanya sampai vaidasi ahli, belum di implemantisakan / uji coba lapangan.

\section{SARAN}

1. Bagi pengguna media big book alfabet diharapkan dapat digunakan secara optimal dan dikemas dengan pembelajaran yang menarik, seperti dikemas dengan permainan serta hal lainnya yang dapat meningkatkan motivasi belajar anak.

2. Media pembelajaran yang peneliti buat jauh dari kata sempurna, peneliti hanya membuat media pembeljaran yang sesuai untuk digunakan dalam proses belajar mengajar. Serta media ini belum peneliti lakukan ke tahap uji coba lapangan, oleh karena itu produk ini dapat di uji cobakan oleh mahsiswa, guru dan pihak lainnya. Selain itu media yang telah dibuat peneliti dapat dikembangkan kembali oleh mahasiswa, guru atau pihak lainnya agar produk ini menjadi lebih baik lagi dari sebelumnya. Serta dapat di modifikasi dengan item yang berbeda sesuai dengan tema yang diinginkan.

\section{DAFTAR PUSTAKA}

Arsyad, A. 2013. Media Pembelajaran. (Cetakan Keenam Belas). Jakarta : PT Raja Grafindo Persada.

Amiel, T., \& Reeves, T. C. (2008). Design-Based Research and 
Educational Technology:

Rethinking Technology and the

Research Agenda. Educational

Technology \& Society, 11

(4),29-40.doi:

http://dx.doi.org/10.5539/ies.v

9n10p155

Gusnita, dkk. (2019). Peningkatan

Kemampuan Mengenal Huruf

Anak Usia Dini Melalui

Alphabet Book Di Taman

Kanak-Kanak. Journal of

Family, Adult, and Early

Childhood Education.Vol.1. No 1.

Mu'awwanah, U. (2018). Pemanfaatan

Big Book Sebagai Media

Literasi Anak Usia Dini.

Journal : Annual Conference on

Islamic Early Childhood

Education. Vol 3.

Nawafilaty, T. (2017). Pengaruh Media

Flash Card Terhadap

Kemampuan Mengenal Huruf

Pada Anak Kelompok A. JCE.

Vol.1. No.1.

Pangastuti dan Hanum. (2017).

Pengenalan Abjad pada Anak

Usia Dini Melalui Media Kartu

Huruf.

INDONESIAN
JOURNAL OF EARLY CHILDHOOD ISLAMIC

EDUCATION. Vol. 1 (1).

Rislina dan Khan. (2015). Mengenalkan Huruf Melalui Loncat Abjad Pada Anak Usia 4-5 Tahun. Nusantara of Reseacrch Jornal. Vol.2. No 2.

Solehuddin, dkk. 2009. Pembaharuan Pendidikan TK. Jakarta: Universitas Terbuka.

Sulaiman, U. (2017). Pengaruh Penggunaan Media Big Book dalam Pembelajaran Terhadap Keterampilan Literasi Siswa Kelas Awal Madrasah Ibtibadiyah Negeri BantaBantaeng Makassar. Jurnal alKalam. Vol. 11. No 2.

Syaripudin dan Kurniasih. 2017. Pedagogik Teoritis Sistematis. Bandung : Percikan Ilmu.

Wiyani. 2014. Psikologi Perkembengan Anak Usia Dini. (Cetakan kesatu) . Yogyakarta : Gava Media.

Zaman dan Eliyawati. (2010). Media Pembelajaran Anak Usia Dini. (Bahan Ajar PPG). Universitas Pendidikan Indonesia, Bandung. 